\title{
Ixodid Ticks (Arachnida: Acari) Prevalence Associated with Risk Factors in the Bovine Host in District Quetta, Balochistan
}

\author{
Nosheen Rafiq ${ }^{1}$, Asmatullah Kakar ${ }^{2, *}$, Arshad Ghani ${ }^{3}$, Asim Iqbal', \\ Wali Mohammad Achakzai ${ }^{2}$, Shagufta Sadozai ${ }^{2}$, Mohammad Shafiq ${ }^{4}$ \\ and Mohammad Alam Mengal ${ }^{5}$ \\ ${ }^{1}$ Department of Zoology, Sardar Bahadur Khan Woman University, Quetta-87300, \\ Pakistan \\ ${ }^{2}$ Department of Zoology, University of Balochistan, Quetta-87300, Pakistan \\ ${ }^{3}$ Government College of Agriculture, Baleli, Quetta-87300, Pakistan \\ ${ }^{4}$ Department of Commerce, University of Balochistan, Quetta-87300, Pakistan \\ ${ }^{5}$ Center for Advanced Studies in Vaccinology and Biotechnology, University of \\ Balochistan, Quetta-87300, Pakistan
}

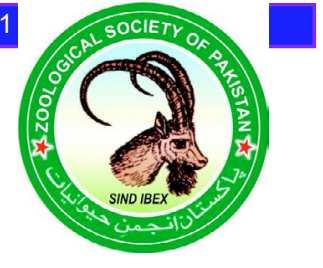

CrossMark

\begin{abstract}
A B S T R A C T
The present study aimed at determining the hard tick species and their abundance with respect to hostrelated risk factors in Bos permiginu $s$ cattle was conducted in farm houses at three main regions (Western by-pass, Spiny village, and Sariab region) of District Quetta from March, 2013 to March, 2014. Around 1649 ticks were captured from six main body parts of 404 cattle. Of these $346(65.96 \%)$ were observed to be plagued by one or more tick infestation. Compositions of tick species captured from the host were Hyalomma anatolicum anatolicum (33.39\%), followed by Dermacenter andersoni (31.76\%), Hyalomma aegyptium (26.16\%), and Boophilus microplus (8.67\%). The risk factor like sex and age of cattle did not demonstrate enormous relationship with the infestation ratio but rather there was relationship with both breeds and body conditions. The commonness of tick infestation in medium body condition (92.9\%), poor body condition $(57.44 \%)$, and good body condition $(87.39 \%)$ was observed to be significant at $\mathrm{P}$-value $(\mathrm{P}<0.01)$ among the three body. Analysis of sex wise tick counting with age of animals revealed positive and significant correlation $(\mathrm{P}=0.1145, \mathrm{P}<0.05)$. The ratio of tick infestation was observed to be insignificant $(\mathrm{P}<0.01)$ among the breeds, with most elevated prepotency in local $(88.97 \%)$ and cross breeds $(13.33 \%)$, respectively.
\end{abstract}

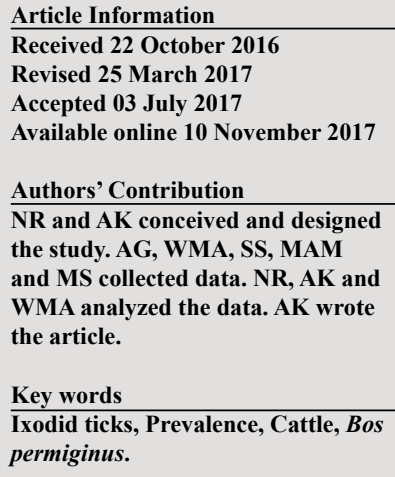

\section{INTRODUCTION}

I xodid ticks (Acari: Ixodidae) are of global veterinary and public health concern (Jongejan and Uilenberg, 1994) that directly cause poor health and loss of production to their vertebrate hosts (Jonsson, 2006). They transmit a wider variety of pathogen than any other arthropods (Iqbal et al., 2016). Some tick species have retained a predilection for cold-blooded vertebrates. Amblyomma rotundatum (Koch, 1844) is an ixodid tick that infests ectothermic animals reported to infest reptiles and amphibians (Rodrigues et al., 2010). Ticks are generally of 3 types identified as hard ticks, soft ticks and Nuttalliella (the combination of hard and soft ticks) (Guglielmon et al., 2010). Ticks have worldwide distribution and have a

\footnotetext{
Corresponding author: asmardanzai@yahoo.com 0030-9923/2017/0006-2113 \$ 9.00/0

Copyright 2017 Zoological Society of Pakistan
}

preference humid and temperate atmosphere and typically attach to the legs, under arms and abdomen of their host body (Nuttal, 1905). They suck host blood during their lengthy attachment period (7-14 days), which may be extended depending on the tick species and unique host association (El Hakim et al., 2007; Perveen et al., 2010). Tick infestation decrease quality of skin (hide) up to 20$30 \%$ (Gharbi et al., 2006) and causes severe anemia, weakness and immunosuppression in the infected animals (Gwakisa et al., 2001).

All the dairy animal species are apt to tick infestation. Because of voracious habit of parasite's blood sucking; loss of blood for their rapid development impoverishes the hosts. In heavy infestation cattle must have more feed merely to meet the demands of the parasites; hence the growth of young animals is retarded, and they may remain thin, weak and stunted. In dairy cows, milk production is greatly reduced. Although, economic losses due to ticks are mainly due to the diseases which they transmit (Garcia, 
2003; Atif et al., 2012b). Numerous species of hard ticks including those from the genera Boophilus, Haemaphysalis, Hyalomma, Amblyomma and Rhipicephalus are reported infesting cows, buffalo and other cattle in India and other parts of the world (Shahardar et al., 1998). Globally tick infestation is causing loss of Rs. 560 billion in the animals with the deterioration of host health, including weight loss and breeding success (Imamura et al., 2008).

In Pakistan, there are more than 62.9 million of cattle and buffaloes, 85.7 millions of sheep and goats and 1.0 millions of camels (Anonymous, 2010). Prevalence of Hyalomma species in Pakistan is significantly higher ( $>0.05$ ) than Haemaphysalis, Amblyomma and Boophilus species of hard ticks (Ali et al., 2009) and reported to be the most prevalent member of Ixodidae (hard ticks) infests buffalo, cattle and other wild animals in countries of Africa, Europe, Middle East and South Asia (Dumanli et al., 2005; Ahmad and Ahmad, 2007; Asmaa, 2012; Hassan and Al-Zubaidi, 2014; Farooqi et al., 2017).

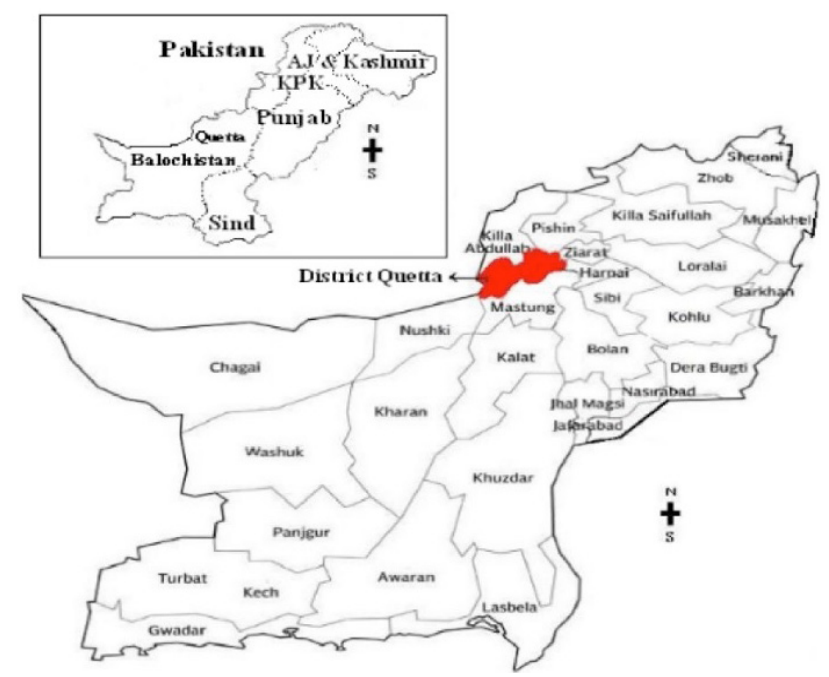

Fig. 1. Map of Balochistan province showing district Quetta.

Ticks as parasitic feeders on blood of cattle and as vector of pathogenic microorganisms reported to destabilize the health and fecundity of domestic animals in Balochistan province (Pakistan) (Iqbal and Nawaz, 2007; Iqbal et al., 2009). Given that the farm animals have become an integral part of the province (Balochistan) economy. Therefore, to meet the demand of animal (cattle) protein, it is timely to identify gaps in the knowledge of tick infestation and diseases in the region. Although, there have been some published data on prevalence of ticks infestation in sheep and goats of Balochistan (Iqbal et al., 2009), but not a single report is available on prevalence, distribution and rick factors (sex and age) of bovine tick species in district Quetta. This article describes preponderance of hard ticks (Ixodidae) on domestic cow breed, Bos permiginus and categorize the major tick's species in relation to both breed and body condition of cattle in the proposed areas of study in district Quetta.

\section{MATERIALS AND METHODS}

Study site

The study was carried out in three administrative domains (Sariab region, Western bypass and Spinny village) from March 2013 to March 2014 in district Quetta (Balochistan), Pakistan (Figs. 1, 2). The area is typical basin of highlands $\left(30^{\circ}-03^{\prime}\right.$ and $30^{\circ}-27^{\prime} \mathrm{N}, 66^{\circ}-44^{\prime}$ and $67^{\circ}-18^{\prime}$ E.) in province with an average annual rainfall of around $269 \mathrm{~mm}$ and 1700 meter elevation and one of the main milk producing regions in the district (Fig. 3).

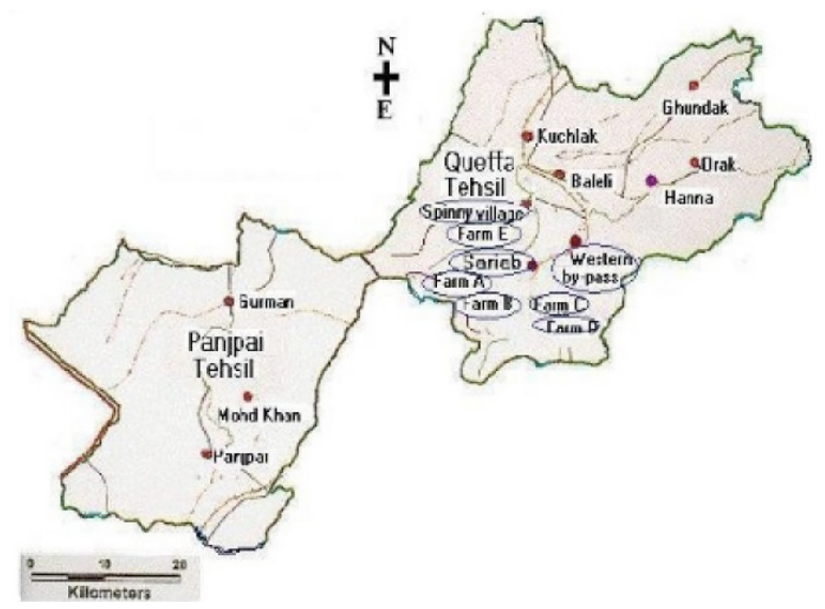

Fig. 2. Map of district Quetta. Blue circles showing study area.

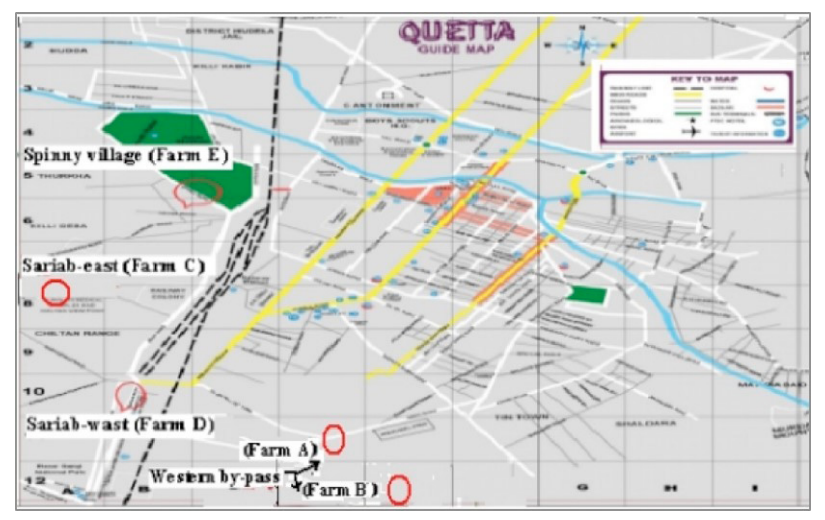

Fig. 3. District Quetta guide map. Red circles showing area of study. 


\section{Tick collection}

All visible adult ticks were detached carefully with the help of blunt steel forceps from different body parts (head, ear, neck, body trunk, ventrum, and extremities etc.) from at least 404 domestic cow breed (mean number $=346$ ) varying in age, sex and breed. Collected ticks were brought to the laboratory, counted and preserved in bottles containing $70 \%$ ethanol. Each bottle was then labeled denoting the host body region of attachment, collection date and locality.

\section{Ticks identification}

Adult ticks were morphologically identified to the species level using dissecting (40X) and compound microscopes (Olympus CH4-DS, Japan) The tick genera naming was made according to the keys and descriptions given by Kaiser and Hoogstraal (1963), Horak et al. (2002) and Lloyed (2004). Permanent slides were prepared followed methods mentioned by Walker et al. (2003).

Prevalence of ticks was calculated as:

$$
\text { Prevalence }(\mathrm{P})=\frac{\text { No of hosts observed }}{\text { No of hosts infested }} \times 100
$$

\section{Statistical analysis}

The data was analyzed using Statistical Package Minitab Version 11.5 for Windows 2000. Chi-square test was used to determine relationship between sex and age/ breed of host and ticks.

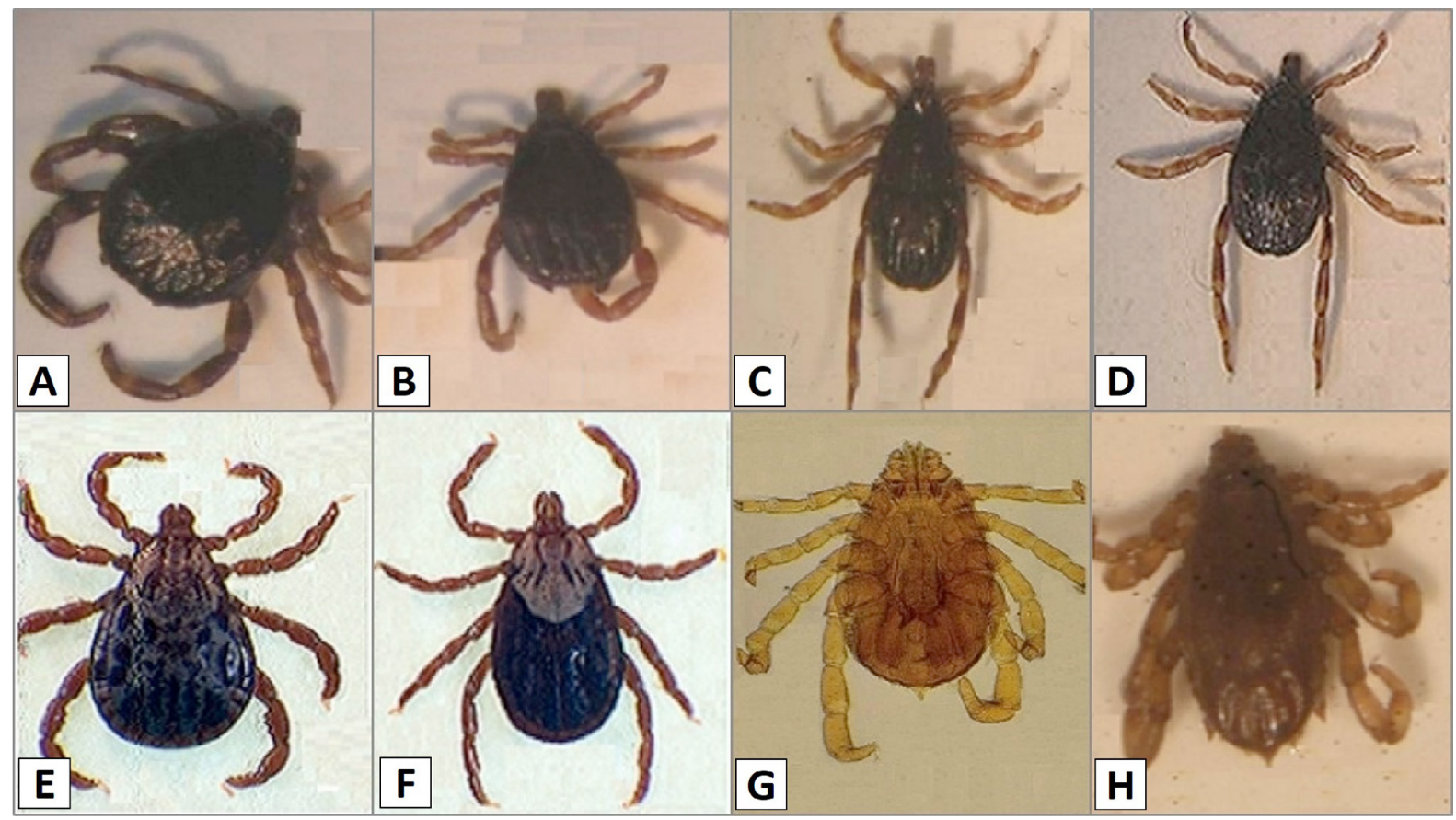

Fig. 4. Three genera of ticks collected from the cattle species from selected farms in Quetta, Balochistan. Dorsal view of Hyalomma male (A), Hyalomma female (B), Hyalomma aegyptium male (C), Hyalomma aegyptium female (D), Dermacenter andersoni male (E), Dermacenter andersoni female (F), Boophilus microplus male (G) and Boophilus microplus female (H). Photographs indicate $30 \mathrm{~mm}$.

Table I.- Sex wise tick count and age of animals analyzed during the study period from March, 2013 to March, 2014.

\begin{tabular}{|c|c|c|c|c|c|c|}
\hline \multirow[t]{2}{*}{ Tick species } & \multicolumn{2}{|c|}{ Tick count } & \multirow[t]{2}{*}{ Total No. } & \multirow{2}{*}{$\begin{array}{c}\text { Percentage } \\
(\%)\end{array}$} & \multirow[t]{2}{*}{ Mean \pm SD } & \multirow{2}{*}{$\begin{array}{c}\text { Age of animal } \\
\text { (Year) }\end{array}$} \\
\hline & Male & Female & & & & \\
\hline Hyalolmma a. anatolicum & 284 & 260 & 544 & 33.39 & $544 \pm 5.53$ & 4 \\
\hline Hyalolmma aegyptium & 270 & 172 & 442 & 26.16 & $442 \pm 2.45$ & 2 \\
\hline Dermacenter andersoni & 263 & 256 & 529 & 31.76 & $529 \pm 2.93$ & 3 \\
\hline Boophilus microplus & 59 & 85 & 144 & 8.67 & $144 \pm 1.26$ & 1 \\
\hline Total & 876 & 773 & 1649 & & & \\
\hline
\end{tabular}

The chi-square statistics is 11.032 . The $\mathrm{P}$-value is 0.1154 . The result is significant at $(\mathrm{P}<0.05)$. 


\section{RESULTS}

In this study a total of 1649 ixodid ticks (876 males and 773 females) (Table I) were sampled from six different body parts of 404 cattle of local $(n=254)$ and cross $(n=150)$ breeds. Of the total cattle, $346(85.64 \%)$ were found to be positive for tick infestation (Tables II, III). However, the tick parasite may also infest the udder, dewlap, anal area and tail of host body (Nibret et al., 2012). The statistical analysis was done for the prevalence of tick infestation with hypothesized risk factors (age, sex, breed and body condition). Three tick genera Hyalomma, Dermacentor and Rhipicephalus, and four species include H. anatolicum anatolicum (Koch, 1844), H. aegyptium (Linnaeus, 1758), D. andersoni (Stiles, 1908) and Rhipicepalus (Boophilus) microplus (Canestrini, 1988) were identified from the infested cow breeds, Bos permiginus (Fig. 4). Compositions of parasite species captured were $33.39 \%(H$. anatolicum anatolicum), 26.16\% (H. aegyptium), 31.76\% (D. andersoni) and $8.67 \%$ (B. microplus), respectively. Mean tick infestation recorded were relatively high $(373+3.85)$ in the neck of the host followed by ear pinnae $(344+3.20)$, body trunk $(267 \pm 2.30)$, head $(180 \pm 2.20)$, ventrum $(137 \pm 2.20)$ and extremities $(45 \pm 1.21)$ as shown in Table II. In this regard highly significant $(P=0.0001)$ difference was found between neck and extremities region of domestic cow breed. There was statistical significant difference between all tick species $(\mathrm{P}<0.05)$ (Table I) and attachment site of ticks to host (Table II). Male specimens of tick outnumbered females for most species except for the Boophilus sp. (Table I). Area wise tick infestation observed was $20.8 \%$ and $20.98 \%$ and $1 \%$, respectively in farm A, B and C of western by-pass; it was $19.28 \%$ in Sariab region, while the noted average in cattle farm-E of Spinny village was $17.22 \%$. Regarding the general incidence of tick species significant relationship $(\mathrm{P}<0.05)$ was found in the present study (Table IV).

Table II.- Total count of adult tick species on different body parts of domestic cow breeds, Bovis Permiginus the study period from March, 2013 to March, 2014.

\begin{tabular}{lccc}
\hline Body parts & \multicolumn{3}{c}{ Ticks } \\
\cline { 2 - 4 } & No. of ticks & Percentage (\%) & Mean \pm SD \\
\hline Head & 180 & 13.37 & $180 \pm 2.20$ \\
Ear pinnae & 344 & 25.55 & $344 \pm 3.32$ \\
Neck & 373 & 27.71 & $373 \pm 3.85$ \\
Body trunk & 267 & 19.83 & $267 \pm 2.30$ \\
Ventrum & 137 & 10.17 & $137 \pm 2.20$ \\
Extremities & 45 & 3.34 & $45 \pm 1.21$ \\
P & & & 0.0000 \\
\hline
\end{tabular}

$\mathrm{P}<0.0001$.

Table III.- Prevalence of ticks in relation to body condition and breed of animals.

\begin{tabular}{|c|c|c|c|c|c|c|}
\hline \multirow[t]{2}{*}{ Breed of animals } & \multicolumn{3}{|c|}{ Parameter } & \multicolumn{3}{|c|}{ Number of animals with body condition } \\
\hline & $\begin{array}{c}\text { No. of animals } \\
\text { examined }\end{array}$ & $\begin{array}{c}\text { No. of animals } \\
\text { infested }\end{array}$ & $\begin{array}{c}\text { Prevalence } \\
(\%)\end{array}$ & Good & Medium & Poor \\
\hline Local & 254 & 226 & 88.97 & 230 & 127 & 47 \\
\hline Cross & 150 & 120 & 13.33 & 201 & 118 & 27 \\
\hline Total No. of cattle & 404 & 346 & - & - & - & - \\
\hline Over all prevalence $(\%)$ & 85.6 & 53.0 & - & 87.39 & 92.9 & 57.44 \\
\hline
\end{tabular}

Body condition, Chi-square statistics is 4.088. P-value is 0.1295 . Result is not significant at $\mathrm{P}<0$ 01; Breed, The chi-square statistics is 0.1593 . P-value is 0.6897 . Result is not significant at $\mathrm{P}<0.01$.

Table IV.- Distribution of ticks incidence in Bovis permiginus in different cattle farms during the study period from March, 2013 to March, 2014.

\begin{tabular}{|c|c|c|c|c|c|c|c|}
\hline \multirow[t]{2}{*}{ Farm } & \multirow[t]{2}{*}{ Location } & \multicolumn{4}{|c|}{ Ticks species } & \multirow[t]{2}{*}{ Total No. } & \multirow{2}{*}{$\begin{array}{c}\text { Percentage } \\
(\%)\end{array}$} \\
\hline & & $\begin{array}{c}\text { Hylomma a. } \\
\text { anatolicum }\end{array}$ & $\begin{array}{l}\text { Hylomma } \\
\text { aegyptium }\end{array}$ & $\begin{array}{c}\text { Dermacenter } \\
\text { anderoni }\end{array}$ & $\begin{array}{l}\text { Boophilus } \\
\text { microplus }\end{array}$ & & \\
\hline Farm A & Western by-pass & 109 & 88 & 116 & 30 & 343 & 20.8 \\
\hline Farm B & Western by-pass & 127 & 83 & 108 & 28 & 346 & 20.98 \\
\hline Farm C & Sariab east & 105 & 103 & 113 & 37 & 358 & 21.71 \\
\hline Farm D & Sariab west & 106 & 92 & 97 & 23 & 318 & 19.28 \\
\hline $\begin{array}{l}\text { Farm E } \\
\text { Grand total }\end{array}$ & Spinny village & 97 & 68 & 93 & 26 & $\begin{array}{c}284 \\
1649\end{array}$ & 17.22 \\
\hline
\end{tabular}

The $f$ value is 258.47502 applying ANOVA. The result is significant at $(\mathrm{P}<0.05)$. 
Infestation by the tick species in local and cross breed was compared: cross breed cattle were found to be less infested $(13.33 \%, \mathrm{n}=120)$ than locally domesticated breeds of cow $(88.97, n=226)$. No statistically significant $(\mathrm{P}=0.1295)$ difference was found comparing body condition with breeds (Table III). Cattle body condition was found to be varied as for as the tick infestation rate is concerned. As a result, tick prevalence was more (92.9\%) on medium condition compared to cattle having good health $(87.39 \%)$ and poor body $(57.44 \%)$ conditions. These results are in line with those reported by Tadesse and Sultan (2014) who found that cattle with medium body condition have significantly $(\mathrm{P}<0.02)$ higher tick infestation. But reports of Walelign and Mekuriaw (2016) and Kemal et al. (2016) do not agree with our results where poor body showed significant burden $(100 \%)$ than cattle with the other body condition scores (medium: 94.7\%) and (good: 32.2\%). On the other hand occurrence contrast between various age groups demonstrates the nearness of high prevalence of ticks in most cattle with age one to four years (Table I). Results revealed significant difference between tick counts and animals age $(\mathrm{P}<0.05)$ using Chi-square test (Table I).

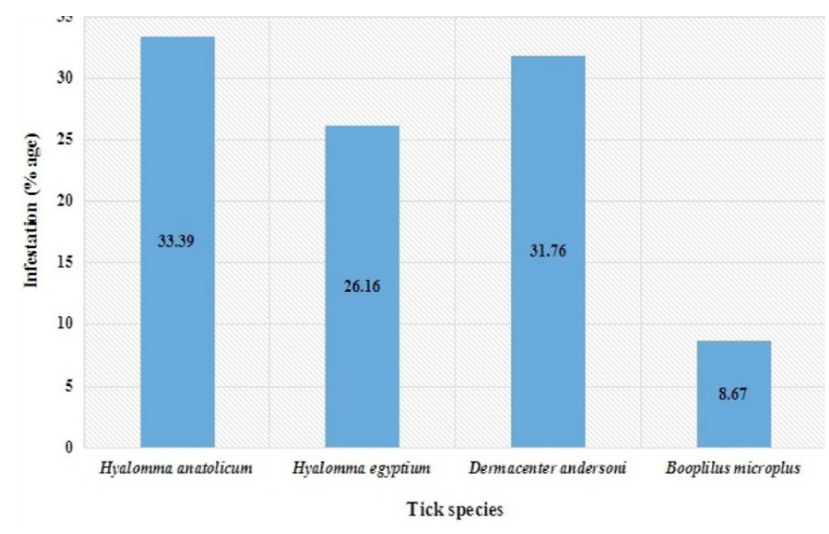

Fig. 5. Distribution ratio of three genera and four species of ixodid tick parasite collected from domestic cow breed, Bovis permiginus in district Quetta.

\section{DISCUSSION}

The faunistic survey of bovine tick prevalence and related risk elements in the study zone has not yet been investigated. In this study it was observed that distribution and abundance of tick species infesting domestic cow breed, Bos permiginus (Linnaeus, 1758) were differ from one locality to another. This variation may be due to the change in environmental conditions that highly affect the ecology of ticks. Change in temperature and rainfall have been reported to affect the distribution of ticks vectors (Taylor et al., 2007). Aktas et al. (2004) reported 85\% humidity and $26^{\circ} \mathrm{C}$ to $37^{\circ} \mathrm{C}$ temperature requirements for growth and reproduction of ticks. This is in contrast to previous studies and suggests that it is not favorable for the ticks to be present in higher humidity (Huba et al., 2003); as they become prone to over saturation thus limiting their activities (Gray, 2007). Of the total observed (346 out of 404) Bos permiginus, (85.64) were found tick infested with highest rate $(65.96 \%)$. The most prevalent tick species affecting domestic cow breed was $H$. a. anatolicum (33. $39 \%$ ) compared to D. andersoni (31.76), H. aegyptium (26.16\%) and B. microplus (8.67\%) (Figs. 4, 5). During summer months infestation in cattle were found highly significant $(\mathrm{P}<0.01)$. The upshot of warmth and moisture on prevalence of Hyalomma abundance was observed, and it was found that on average, the warmest month was July (Year 2013-2014) in Quetta where maximum average hotness rise up to $36^{\circ} \mathrm{C}$, and moisture $42 \%$ greatly increased the occurrence of tick species. Khan et al. (1993) attributed an increase tick infestation during summer months due to an increase temperature and humidity. Their study on different livestock species reported 28.2 and $14.7 \%$ infestation in cattle and buffaloes, respectively. Hyalomma were the most prevailing tick species in cattle and buffalo followed by those belonging to Boophilus. This is in agreement with the findings of present study and those presented by Mustafa et al. (2014) and Tassarwar et al. (2014) who reported the highest prevalence (37\%) of Hyalomma a. anatolicum and considered it the most wide spread and commonest cattle tick in Punjab province (Pakistan).

Nearly similar results were found by Atif et al. (2012a) where they recorded 22.86\%, Hyalomma $a$. anotolicum tick followed by Rhipicephalus (Boophilus) microplus $(21.33 \%), R$. (B.) sanguineus $(7.52 \%), R$. (B.) annulatus (1.43\%) and Haemaphysalis spp. (1.62\%) they noted maximum (mean) temperature to be involved in high prevalence of tick infestation. Other researchers like ? Biu et al. (2012) described Hyalomma ticks as the most prevalent species $(18.27 \%)$ reported infesting small ruminants of Nigeria. Similar finding were reported by other scientists in Pakistan. Durrani et al. (2008) recorded $66.7 \%$ prevalence of cattle Hyalomma tick in district Lahore. Manan et al. (2007) surveyed tick fauna in outskirts of Peshawar resulted two tick's genera Rhipicephalus (Boophilus) and Hyalomma as the most prevalent ticks showed $46.1 \%$ and $31.25 \%$ infestation, respectively. Ali et al. (2013) analyzed an overall tick prevalence reported Hyalomma as dominant (61\%) over other genera of hard ticks. Female Hyalomma was highest in sex-wise dispersion (85\%) than Amblyomma (81\%), Boophilus and Haemaphysalis species (77\%). Cows were examined to be more infested (70\%) than buffaloes (34\%). This situation 
may occurs due to brooding period, age, or sex (Alonso et al., 2007), host accessibility or dietary status of the animal (Yacob et al., 2008).

Previous studies notably those by above Alekaw (1998) stated less prevalence (5.7\%) of Hyalomma in the cattle of Metekel Ranch, Ethiopia. The female ticks were noted to be abundant transmitted Babesia bigemina to cattle of this region. These results however, disagree with our findings and with those reported by Shahardar et al. (1998) in bovine farm animals found infested with $40 \%, 20.14 \%, 16.96 \%$, prevalence ratio by Boophilus, Hyalomma, Haemaphysalis while Amblyomma, Nosoma and Rhipicephalus caused 10.22\%, 4.56\% and 1.96\%, respectively at Maharashtra, India.

The present study is to some degree comparable to studies conducted earlier in other parts of the world. Reports of Tiki and Addis (2011) and Onu and Shiferaw (2013) demonstrated comparatively less prevalence ratio (25.64) and (14.5\%) of Hyalomma and Boophilus ticks, respectively. This difference may occur because of lactation phase of the tick (Teel et al., 1996), variation in agro-climatic condition of the study region. Since high infestation ratio $(65.96 \%)$ of tick species prevalence was determined in the present study during March, 2013 to March, 2014. On the other hand, Fantahun and Mohamed (2012) reported 70.3\% infestation in cattle of Assona town, Ethiopia in contrast to $48.2 \%$ described by Tamiru and Abebaw (2010) in local and cross breeds of cattle in Asella Town, south west Ethiopia. These findings are not in line with findings of the present study and those reported by above mentioned authors. This distinction may because of change in the climatic factors (Greenfield, 2011), breed, body condition (Hassan and Osman, 2003), and farming practices (Bianchi et al., 2003).

Regarding the associated risk factors, tick infestation was found statistically significant $(\mathrm{P}<0.05)$. The local cow breed (Bos periginus) were found highly infested $(88.97 \%)$ than cross breed $(13.33 \%)$ cattle (Table III). These results go in accordance with those reported by Kabir et al. (2011) was significantly $(\mathrm{P}<0.01)$ higher in local cattle $(43.82 \%)$ than the crossbred $(24.13 \%)$ cattle. Results in Table I denoted that older ages (4 years animals) were found more infested (32.9\%) than animals at the age of 2 years $(26.8 \%), 3$ (31.4), and one year old showed $8.7 \%$ infestation. The percent distribution on different body parts of analyzed cattle (Table III) revealed the neck (27.71), and ear pinnae (25.55) as the most preference sites of tick infestation followed by body trunk (19.83), head (13.37), ventrum (10.17) and extremities (3.34\%). The reason for the results may be highly supplied with blood to neck and ear pinnae region of the body. Ticks usually prefer thinner and short hair skin for infestation, this helps in easy penetration of mouth parts into richly vascular area for feeding (Sajid et al., 2007). Moreover, Atif et al. (2012a) indicated that perineum, udder and external genitalia (98\%) were the most infested tick sites than dewlap (92\%), inner thighs (90\%), neck and back (54\%), tail $(26 \%)$, ears $(13 \%)$, around eyes $(10 \%)$, flanks $(4 \%)$ and legs $(2 \%)$, respectively.

The present study associate the ticks prevalence and ratio of infestation with change in the breed and body condition of the animals. In this regard higher commonness was observed in cattle with medium $(92.9 \%)$ and poor body $(57.44 \%)$ status $(\mathrm{P}=0.01)$. Wasihun and Doda (2013) have reported $79.8 \%$ tick infestationin in medium body than poor body (67.9\%), and animals having good body conditions $(58.0 \%)$. This may be due to that medium body cattle are given to any form of illness when eating on the field, and poor body animal were kept at home because of their impotence to walk in field, so they turn out to be less pervaded than animal's posses medium body status. All about good cattle were resistant especially to any form of illness when they graze in the field or are kept at home. The result demonstrated significant difference between prevalence of tick infestation and the breeds $(\mathrm{P}=0.01)$. The breeds are pervaded peculiarly by the ticks with the commonness $(92.9 \%)$. The vast variety of tick infestation of various cow breeds in the present study may be assigned to compare administration frameworks, absence of subsidiary bolstering that resulted in low resistance to local breeds.

\section{CONCLUSIONS}

In conclusion, Hyalomma a. anatolicum (33.39\%) was the most prevalent among the tick species followed by Dermacenter andersoni (31.76\%), Hyalomma aegyptium (26.16\%) and Boophilus microplus the least prevalent $(8.67 \%)$ recorded in the study. The effect of temperature and humidity on prevalence of Hyalomma ticks abundance was observed, and it was found that on average, the hottest month was July (Year 2013-2014) in Quetta where maximum average temperature rise up to $36^{\circ} \mathrm{C}$, and humidity $42 \%$ greatly enhanced the prevalence of tick species. Hence, it is suggested that distribution of ticks are not fixed but can be determined by a complex interaction of factors such as, atmosphere, host thickness, host susceptibility, grazing and posture herd management. Overall, the present study revealed very high prevalence of tick infestation that could potentially hamper the productivity of cattle in the study area, hence a serious measure should be put in place to control and reduce the adverse effect of tick infestation. Thus, influential tick control system ought to be formulated taking into account 
the dispersion pattern of ticks and aspects liable for their distribution. It would be beneficial to evaluate the levels of tick prevalence infestation and transmissible pathogens present within study locations relating not only to wild and domestic animal health, but also to public health.

\section{Statement of conflict of interest}

Authors have declared no conflict of interest.

\section{REFERENCES}

Abebaw, G., 2004. Seasonal dynamics and host preference of Boophilus decolaratus on naturally infested cattle in Jimma zone, South Western Ethiopia. Ethiopia Vet. J., 18: 19-28.

Ahmad, N. and Ahmad, H.A.A., 2007. Comparative study on the incidence of ticks and ticks borne diseases on local and crossbred cattle in Malakand agency. J. Anim. Pl. Sci., 17: 56-58.

Ahmed, S., Muhammad, N., Abdul, W. and Mansoor, A.A., 2012. Investigations into Ixodidae ticks in cattle in Lahore Pakistan. Vet. Italainia, 48: $185-$ 191.

Aktas, M., Dumanli, N. and Angin, M., 2004. Cattle infestation by Hyaloma ticks and prevalence of Theileria in Hyalomma species in the East of Turkey. Vet. Parasitol., 119: 1-8. https://doi. org/10.1016/j.vetpar.2003.10.013

Alekaw, S., 1998. Distribution of tick and tick borne 12. Lord, C.C., 2008. Brown dog tick, Rhipicephalus diseases at Metekel Ranch. Ethiopia. Vet. J., 4: 30.

Ali, Z., Maqbool, Z., Muhammad, K., Altaf, I., Khan, M.S., Masood, R., Hanif, A. and Iqbal, J. H., 2009. Antibody response of buffalo calves to montanide based Hyalomma tick homogenate vaccine. Pakistan J. Zool. Suppl. Ser., 9: 167-172.

Ali, Z., Maqbool, A., Muhammad, K., Khan, M.S. and Younis, M., 2013. Prevalence of Theileria annulata infected hard ticks of cattle and buffalo in Punjab, Pakistan. J. Anim. Pl. Sci., 23: 20-26.

Alonso, D.M.A., Lopez, S.B.J., Leme, D.L.A.C. and Rodriguez, V.R.I., 2007. Infestacion natural de hembras de Boophilus microplus Canestrini, 1887 (Acari: Ixodidae) en dos genotipos de bovinos en el tropico humedo de Veracruz, Mexico. Vet. Mexico, 38: 503-509.

Anonymous, 2010. Economic Survey of Pakistan, Ministry of Finance, Government of Pakistan.

Atif, F.A., Khan, M.S., Iqbal, H.J., Ali, Z. and Ullah, S., 2012a. Prevalence of cattle tick infestation in three districts of the Punjab, Pakistan. Pak. J. Sci., 64: 49-53.
Asmaa, A.K.A., 2012. Some studies on hard ticks infesting cattle and buffaloes in Beni-Suef Governorate. MVSc, Fac. Vet. Med. Beni-Suef University.

Atif, F.A., Khan, M.S., Khan, M.A., Ashraf, M. and Avais, M., 2102b. Chemotherapeutic efficacy oxytetracycline, enrofloxacin and imidocarb for the elimination of persistent Anaplasma marginale infection in naturally infected Sahiwal cattle. Pakistan J. Zool., 44: 449-456.

Bianchi, M.W., Barre, N. and Messad, S., 2003. Factors related to cattle infestation level and resistancet to acaricides in Boophilus microplus tick populations in New Caledonia. Vet. Parasitol., 112: 75-89. https://doi.org/10.1016/S0304-4017(02)00415-6

Biu, A.A., Rabo, J.S., Dawurung, J.S. and Abubakr, S.I.G., 2012. Survey study on the tick fauna of small ruminants on the University of Maiduguri Research Farm (UMRF), Nigeria. Acad. Arena, 4: 1-3.

Bourne, A.S., Sutherst, R.W., Sutherland, I.D., Maywald, G.F. and Stegeman, D.A., 1988. Ecology of the cattle tick Boophilus microplus in subtropical Australia. III. Modelling populations on different breeds of cattle. Aust. J. agric. Res., 39: 309-318. https://doi.org/10.1071/AR9880309

Dumanli, N., Aktas, M., Cetinkaya, B., Cakmak, A.E., Saki, C.E., Erdogmus, Z., Nalbantoglu, S., Ongor H., Simsek, S., Karahan, M. and Altay, K., 2005. Prevalence and distribution of tropical theileriosis in eastern Turkey. Vet. Parasitol., 127: 9-15.

Durrani, A.Z., Shakoori, A.R. and Kamal, N., 2008. Bionomics of Hyalomma ticks in three districts of Punjab, Pakistan. J. Anim. Pl. Sci., 1: 17-23.

El Hakim, A.E., Shahein, Y.E., Aboelella, A.M.K. and Selim, M.E., 2007. Purification and characterization of two larval glycoproteins from cattle tick Boophilus annulatus. J. Vet. Sci., 8: 175-180 https:// doi.org/10.4142/jvs.2007.8.2.175

Fantahun, B. and Mohamed, A., 2012. Survey on the distribution of tick species in and around Assosa Town, Ethiopia. Res. J. Vet. Sci., 7: 124-131. https:// doi.org/10.3923/rjvs.2012.32.41

Farooqi, S.H., Saleem, M.H., Rashid, M.I.,Oneeb, I., Khan, M., Aqib, A.I. and Mahmood, S., 2017. Distribution of ixodid tick species and associated risk factors in temporal zones of Khyber Pakhtunkhwa Province, Pakistan. Pakistan J. Zool., 49: 2011-2017.

Garcia, Z., 2003. Integrated control of Boophilus microplus in cattle. In: Proc. $11^{\text {th }}$ Int. Congr. Int. Society for Animal Hygiene. Mexico City, Mexico. 
Gharbi, M., Sassi, L., Dorchies, P., and Darghouth, P., 2006. Infection of calves with Theileria annulata in Tunasia: Economic analysis and evaluation of the potential benefit of vaccination. Vet. Parasitol. 137:231-241.

Gray, J., 2007. Ixodes ricinus seasonal activity: implication of global indicated by revisiting tick and weather data. Int. J. med. Microbiol., 298: 1924. https://doi.org/10.1016/j.ijmm.2007.09.005

Greenfield, B.P.J., 2011. Environmental parameters affecting tick (Ixodes ricinus) distribution during the summer season in Richmond Park, London. Biosci. Horizons, 4: 140-148. https://doi. org/10.1093/biohorizons/hzr016

Guglielmone, A., Robbing, R.G., Apanaskevich, D.A., Petney, T.N., Estrada-Peña, A., Horak, I.G., Renfu, S. and Barker, S., 2010. The Argasidae, Ixodidae and Nuttalliellidae (Acari: Ixodida) of the world: a list of valid species names. Zootaxa, 2528: 1-28.

Gwakisa, P., Yoshihara, K., Long, T.T., Gotoh, H., Amano, F. and Eiichi, M., 2001. Salivary gland extract of Rhipicephalus appendiculatus ticks inhibits in vitro transcription and secretion of cytokines and production of nitric oxide by LPS stimulated JA-4 cells. Vet. Parasitol., 99: 53-61.

Hassan, R.H. and Al-Zubaidi, H.H., 2014. Cattle and buffaloes tick's infestation in Wasit province, Kufa districts, Iraq. J. Vet. Med. Sci. 5: 31-40.

Hassan, S.M. and Osman, A.M., 2003. Ecological and biological factors determining population dynamics of ixodid ticks: A review. Sudan. J. Vet. Sci. Anim. Husb., 42: 16-44.

Horak, I.G., Camicas, J.L. and Kierans, J.E., 2002. The argasidae, ixodidae and Nuttalliellidae (Acari: Ixodida): A world list of valid tick names. Exp. appl. Acarol., 28: 27-54. https://doi. org/10.1023/A:1025381712339

Huba, Z., Halouzka, J. and Juricova, Z., 2003. Hostseeking activity of ixodid ticks in relation to weather variables. J. Vector Ecol., 28: 159-165.

Immura, S., Konai, S., Vaz, I. S., Yamada, C., Nakajima, C., Ito, Y., Tajima, T., Yasuda, J., Simuunza, M., Onuma, M. and Ohashi, K., 2008. Effect of anti-tick cocktail vaccine against Rhipicephalus appendiculatus. Jpn. J. Vet. Res., 56: 85-98.

Iqbal, A., Nawaz, M., Mujeebur-Rehman, Shahabuddin, Kamran, K., Muhammad, W. and Dastagir, G., 2009. Extraction of attachment cement cone protein from larval tick Haemaphysalis flava, as stage reactive immunogen in domestic sheep breed Ovis aries baluchii from Balochistan, Pakistan. Pak. Entomol., 31: 57-41.
Iqbal, A., Asmatullah-Kakar, Mujeebur-Rehman, Iram, S., Gul, S. and Panezai, A.M., 2016. Analysis of immune response in goats Capra hircus lehri against different doses of cement cone extract antigen taken from ticks (Ixodidae) emulsified with different adjuvants. Pakistan J. Zool., 48: 11791184.

Iqbal, A., Sajid, M.S., Khan, M.N. and Muhammad, G., 2014. Epizootiology of ectoparasitic fauna infesting selected domestic cattle population of Punjab, Pakistan. Int. J. Agric. Biol., 16: 443-446.

Iqbal, A. and Nawaz, M., 2007. Taxonomic studies of Haemaphysalis flava (Neuman), its seasonal prevalence and role in parasitic disease of sheep / goat in Balochistan. Pak. Entomol., 29: 1-4.

Jongejan, F. and Uilenberg, G., 1994. Ticks and control methods. Rev. Sci. Tech., 13: 1201-1226. https:// doi.org/10.20506/rst.13.4.818

Jonsson, N.N., 2006. The productivity effects of cattle tick (Boophilus microplus) infestation on cattle, with particular reference to Bos indicus cattle and their crosses. Vet. Parasitol., 137: 1-10. https://doi. org/10.1016/j.vetpar.2006.01.010

Kabir, M.H.B., Mondal, M.M.H., Eliyas, M., Mannan, M.A., Hashem, M.A., Debnath, N.C., Miazi, O.F., Mohiuddin, C., Kashem, M.A. and Debnath, N.C., 2011. An epidemiological survey on investigation of tick infestation in cattle at Chittagong District, Bangladesh. Afr. J. Microbiol. Res., 5: 346-352.

Kaiser, M.N. and Hoogstraal, H., 1964. Hyalomma ticks (Ixodoidea, Ixodidae) of Pakistan India and Ceylon with keys of subgenera and species. Acarologia, 2: 257-286.

Kemal, J., Muktar, Y. and Alemu, S., 2016. Distribution and prevalence of tick infestation in cattle in Babille district, eastern Ethiopia. Livest. Res. Rural Dev., 28: 1-12.

Khan, M.N., Hayat, C.S., Iqbal, Z., Hayat, B. and Naseem, A., 1993. Prevalence of ticks on livestock in Faisalabad. Pak. Vet. J., 13: 182-184.

Lloyd, D.H., 2004. Mites and ticks of domestic animals. An identification guide and information source. Vet. Dermatol., 15: 266-269. https://doi.org/10.1111/ j.1365-3164.2004.00408.x

Manan, A., Khan, Z., Ahmed, B. and Abdullah, 2007. Prevalence and identification of ixodid tick genera in frontier region, Peshawar. J. Agric. biol. Sci., 2: 21-25.

Monfared, A.L., Mohammad, M. and Roohollah, F., 2015. Prevalence of ixodid ticks on cattle, sheep and goats in Ilam County, Ilam Province, Iran. $J$. Parasitol. Dis., 39: 37-40. https://doi.org/10.1007/ 
s12639-013-0267-8

Mustafa, I., Rana, M.K.S., Marghoob, S., Iftikhar, A., Aleem, R., Sadaf, J., Hira, M., Shabbier, R.G., Ghani, A., Mahmood, T., Aslam, M., Khan, M.R., Asif, S., Malik, U., Muhammad, A.B., Aqeel, M.A., Qayyum, M., Waqas, A. and Ahmed, H., 2014. Seasonal activity of tick infestation in goats and buffalo of Punjab province (district Sargodha), Pakistan. Kafkas. Vet. Fak. Derg., 20: 655-662.

Nibret, M., Basaznew, B. and Tewodros, F., 2012. Hard ticks (Ixodidae), species composition, seasonal dynamics and body site distribution on cattle in Chilga district, Northwest Ethiopia. Asian J. agric. Sci., 4: 341-345.

Nuttall, G.H.F., 1905. Ticks and tick-transmitted diseases. Trans. Epidemiol. Soc. London, 24: 1226.

Onu, S.H. and Shiferaw, T.Z., 2013. Prevalence of ectoparasite infestations of cattle in Bench Maji zone, Southwest Ethiopia. Vet. World, 6: 291-294.

Perveen, F., Naqvi, S.N.H. and Yasmin, N., 2010. Ixodid ticks infestation in livestock and their traditional control in NWFP, Pakistan, Pakistan J. Zool., 42: 43-54.

Rodrigues, D.S., Maciel, R., Cunha, M.L., Leite, R.C. and Roberto de Oliveira, P., 2010. Amblyomma rotundatum (Koch, 1844) (Acari: Ixodidae) twohost life-cycle on Viperidae snakes. Rev. Bras. Parasitol. Vet. Jaboticabal., 19: 174-178. https:// doi.org/10.1590/S1984-29612010000300009

Sajid, M.S., Iqbal, Z., Khan, M.N., Muhammad, G. and Iqbal, M.U., 2007. Effect of Hyalomma ticks (Acari: Ixodidae) on milk production of dairy buffaloes (Bos bubalus bubalis) of Punjab (Pakistan). Italian J. Anim. Sci., 6: 939-941. https://doi.org/10.4081/ ijas.2007.s2.939

Sajid, M.S, Iqbal, Z, Khan, M.N. and Muhammad, G., 2009. In vitro and in vivo efficacies of ivermectin and cypermethrin against the cattle tick Hyalomma anatolicum anatolicum (Acari:Ixodidae). Parasitol. Res., 105: 1133-1138. https://doi.org/10.1007/ s00436-009-1538-2

Shahardar, R.A., Niphadkar, S.M., Narsapur, V.S. and Gante, M.L., 1998. Ixodid ticks of cattle and buffaloes in coastal district of Konkan region Maharashtra. Indian Vet. J., 75: 503-506.

Tadesse, B. and Sultan, A., 2014. Prevalence and distribution of tick infestation on cattle at Fitche Selale, North Shewa, Ethiopia. Livest. Res. Rural Dev., 26: 34-39.

Tamiru, T. and Abebaw, C., 2010. Prevalence of ticks on local and cross breeds of cattle in and around Asella Town, South West Ethiopia. Ethiopian Vet. J., 14: 79-89.

Tasawar, Z., Nasim, S. and Lashari, M.H., 2014. The prevalence of ixodid ticks on buffaloes at private animal farm Bibipur, Multan. Glob. Vet., 12: 154157.

Taylor, M.A., Coop, R.H. and Wall, R.L., 2007. Veterinary parasitology ( $3^{\text {rd }}$ ed.). BlackWell Publishing, London, pp. 679-712.

Teel, P.D., Marin, S.L. and Grant, W.E., 1996. Simulation of host parasite landscape interactions: influence of season and habitat on cattle fever tick (Boophilus sp.) population dynamics. Ecol. Model., 84: 19-30. https://doi.org/10.1016/0304-3800(94)00142-1

Tiki, B. and Addis, M., 2011. Distribution of ixodid ticks on cattle in and around Holetta Town, Ethiopia. Glob. Vet., 7: 527-531.

Walelion, R. and Kekuriaw, F., 2016. Identification and prevalence of hard tuick in and around Sude Woreda, Arsi Zone, Ethiopia. J. Hlth. med. Nursing, 28: 13-19.

Walker, A.R., Bouattour, J.L., Camicas, A.E., Pena, I. G., Horak, A.A., Latif, R.G. and Pegram, P., 2003. Ticks of domestic animals in Africa: A guide to identification of species. Biosci. Report. Atal. Hout. Nehterland, 74: 218-221.

Wasihun, P. and Doda, D., 2013. Study on prevalence and identification of ticks in Humbo district, Southern Nations, Nationalities, and People's Region (SNNPR), Ethiopia. J. Vet. Med. Anim. Hlth., 5: 73-80.

Yacob, H.T., Ataklty, H. and Kumsa, B., 2008. Major ectoparasites of cattle in and around Mekelle, Northern Ethiopia. Entomol. Res., 38: 126-130. https://doi.org/10.1111/j.1748-5967.2008.00148.x 